\title{
GOVERNMENT EXACTIONS AND REVENUE DEFICIENCIES
}

\author{
Arthur B. Laffer
}

The proposition that increases in tax rates discourage marketsector production and may therefore, beyond a certain level, be counterproductive in raising tax revenue is an old issue in the economic literature. Its recent revival has generated considerable controversy and interest among both economists and policy makers. The resolution of this controversy depends on identifying the empirical relationship between changes in tax rates and changes in economic activity and, hence, in tax revenue. As yet, however, this relationship has been the subject of little systematic empirical analysis.

In the first section of this paper, a simple model of tax rates, output, and revenue is presented. Then we trace some of the historical antecedents of what is now commonly known as the "Laffer curve." Finally, in the third section, we review the evidence of the 1962 and 1964 federal income tax cuts in order to determine their effects on revenue.

\section{Tax Rates, Output, and Revenue: A Simple Model}

In any serious examination of the influence of taxation on economic activity, it is of paramount importance to distinguish between tax revenue and tax rates. Tax revenue may influence economic activity through an income effect, while tax rates operate through a substitution effect. For example, a change in income tax rates generates a substitution effect by altering the relative rewards to market and nonmarket activity.

Cato Joumal, Vol. 1, No. 1 [Spring 1981]. Copyright $\odot$ Cato Institute. All rights reserved.

The author is the Charles B. Thornton Professor of Business Economics at the University of Southern California, Los Angeles 90007. He wishes to thank Prof. Victor A. Canto, also of USC, without whose efforts this paper could not have been completed. 


\section{Cato JOURNAL}

It has long been recognized that within a closed general equilibrium system, a change in relative prices will not ordinarily entail any aggregate income effect. ${ }^{1}$ Whether a tax-induced change in relative prices entails an income effect (before economic agents have modified their behavior in response to the tax rate changel depends on how the government disposes of the resulting incremental revenue. If the proceeds from taxation or their equivalent in public services are disbursed in a manner independent of how the taxes are collected, then the individual income effects will generally, in the absence of collection costs or distribution effects, cancel out, leaving only the substitution effects. If the government uses the tax revenue to produce public services that are neither more nor less valuable than the lost private consumption, then a tax rate change will entail a zero aggregate income effect.

These ideas may be illustrated with a simple static model of tax rates, output, and revenue. ${ }^{2}$ The model assumes that the supply of factors of production to the market sector is determined in part by the net-of-tax factor rewards; the factor supply functions are therefore assumed to be upward-sloping. The demand for factors of production depends on their marginal products; given competition and factor mobility, the factor marginal products will be equal to the gross-of-tax factor rewards. Thus the optimal factor mix used in the production process will depend on relative factor rewards. Only two factors of production are assumed, say labor and capital, and market-sector production is assumed to consist of a simple good that we call market output.

Within this framework, people don't work to pay taxes. Corporate executives don't relocate business facilities as a matter of social conscience. People work in part for after-tax income. Business location decisions are predicated partially on after-tax profit considerations.

A reduction in tax rates on an activity necessarily increases that activity's after-tax profitability. When the after-tax rate of return on an activity is increased, more of the activity will be done and the tax base will expand. Applied to market production, these arguments suggest that the level of market output will be inversely related to the tax rate on market products. Since two factors are used in the production process, the market-product tax rate must be a

1 John R. Hicks, Value and Capital, 2nd ed. \{Oxford University Press, 1946\}, p. 64. 2 For a formal derivation of the model, see Victor A. Canto, Douglas H. Joines, and Arthur B. Laffer, "Taxation, GNP, and Potential GNP," Proceedings of the Business and Economic Statistics Section: 1978 (Washington, D.C.: American Statistical Association, 1978 . 


\section{FIGURE 1 \\ THE ISO-OUTPUT LOCUS}

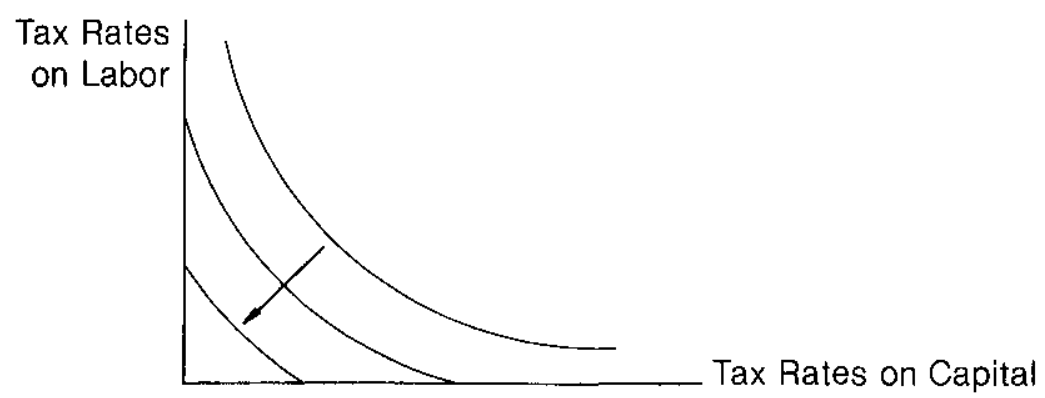

NoTE: The arrow denotes the output direction; that is, the further an iso-output curve is upward and to the right of the origin (where both tax rates are zero), the higher the respective tax rates on capital and labor and the lower the level of output. Notice that the iso-output locus intersects the axes with a positive output fi.e., there is a positive amount produced even if there is no tax levied on one of the factors of production|. Finally, the concavity from above the isoquants reflects the implicit assumption of a diminishing marginal rate of substitution between factor tax rates.

weighted average of the tax rates on the factors of production. Thus it is apparent that there are numerous combinations of tax rates on each of the factors of production that yield the same product tax rate. That is, there are numerous combinations of factor tax rates that yield the same level of output.

In figure 1, a family of the iso-output curve is given. Within this two-factor model containing both capital and labor as well as one market output, the effect on total tax receipts of an increase in the tax on either factor of production has conflicting influences. For example, an increase in the tax rate on labor will elicit the following responses:

1. A scale effect-the increase in labor tax rates will increase unambiguously the effective tax rate on the final product, leading to a reduction in the output of market goods. This in turn will lead to a reduction in the employment of both factors of production.

2. A substitution effect-the tax rate will increase the relative cost of labor services. This induces a substitution effect away from labor into capital services.

It is fairly obvious that in the case of an increase in labor tax rates, the scale and substitution effects reinforce each other, leading to an unambiguous reduction in the employment of labor services. In the case of capital, on the other hand, the scale and substitution effects tend to offset each other. Whether employment of capital services increases or not depends on the relative strength of the two effects. In what follows, the scale effect is assumed to dom- 
inate, in which case the employment of capital services will unambiguously decline.

The increase in the tax wedge on labor will have the following effects:

1. More revenue will be collected per worker; this will tend to increase revenue. Some people call this effect the naive treasury estimate. However, we prefer to call it the arithmetic effect.

2. Fewer workers will be employed; this will tend to lower revenue. We label this effect the direct feedback effect.

3. Less capital will be employed; this will tend to lower revenue. This effect we label the indirect feedback effect.

Under certain circumstances, the additional revenue collected per worker (the arithmetic effect) will predominate, and an increase in the tax wedge on labor will raise revenue. Sometimes the second two effects (the feedback effects) will predominate, and less revenue will be forthcoming. The same set of conditions pertains to changes in the tax wedge on capital.

In actual practice, of course, a number of additional influences are felt. With higher tax rates, there will be more tax avoidance and evasion, which will aggravate the offsetting revenue impact accompanying tax rate increases. Where possible, factor substitution will reduce the economy's reliance on the now higher-taxed factor. The longer the time period allowed to elapse, the greater will be the offsets. The higher the initial level of tax rates, the greater will be the offsets. Overall, the relationship between tax rates and tax revenue is far from obvious. As often as not, higher tax rates yield less revenue; they always yield less output. When a tax rate increase yields higher revenue, the tax is in the normal range. When a tax rate increase leads to lower revenue, it is in the prohibitive range.

One way to analyze the effects of tax rate changes is to specify the combination of tax rate changes on capital and labor where total revenue is left unchanged. This framework is useful because it separates the issues of total spending from those of total tax policies. Thus, if the tax on labor and the tax on capital are both in the normal range, a tax rate reduction on labor will be accompanied by a tax rate increase on capital, or vice versa. On the other hand, if the tax rate on labor is in the prohibitive range while the tax rate on capital is in the normal range, then a tax rate reduction on labor, which by definition would lead to higher revenue, would require a tax rate reduction on capital as well.

A representative pairing of such tax rates on labor and capital can be depicted on a two-axis graph. The horizontal axis is the tax on 


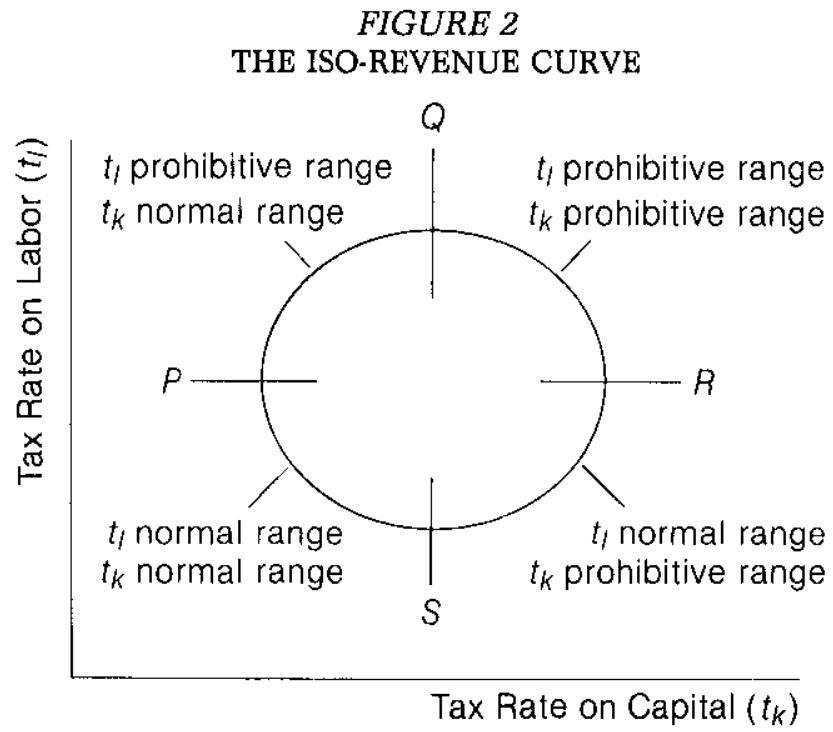

capital, $t_{k}$, and the vertical axis is the tax on labor, $t_{k}$. The locus of points describing the different pairings of tax rates that yield the same amount of tax revenue is named the iso-revenue curve. One such curve is drawn in figure 2 in the form of an ellipse. The location and angle of the ellipse are purely arbitrary, the diagram being for illustrative purposes only. Four distinct regions can be identified on the iso-revenue line. In the region from $P$ to $S$, both tax rates are in their "normal" range; an increase in the tax rate on capital alone, or the tax rate on labor alone, will raise net revenue. Therefore, if revenue is to stay the same in the PS region of the isorevenue line, an increase in either tax rate must be accompanied by a reduction in the other tax rate.

In the $P Q$ region, the tax on labor is in its prohibitive range, while the tax on capital is in its normal range: An increase in the tax rate on labor lowers net revenue, while an increase in the tax on capital raises net revenue. Thus an increase in the tax rate on labor (moving up the vertical axis) must be accompanied by an increase in the tax rate on capital (moving to the right on the horizontal axis) to maintain the same level of revenue. Hence, the iso-revenue line in this region is upward-sloping to the right. Holding revenue constant, the higher the tax rate on labor, the higher must be the tax on capital.

$Q R$ is the region where both tax rates are in the prohibitive range. In this region, an increase in either tax rate lowers revenue. Thus if the tax on capital is increased (movement to the right), the tax rate 


\section{Cato JournaL}

on labor must be reduced (movement down) to keep total revenue constant. The iso-revenue line here is downward-sloping to the right.

Finally, in the region RS, the tax on labor is in the normal range and the tax on capital is in the prohibitive range. Here a rise in the tax rate on labor, which increases revenue, must be accompanied by an increase in the tax rate on capital, which lowers revenue, in order to keep total revenue constant.

In each of the three regions, $P Q, Q R$, and $R S$, at least one tax rate is in the prohibitive range. That is, an increase in the tax rate lowers net revenue. In the region $Q R$, both tax rates are in the prohibitive range. Only in the one region, $P S$, are both tax rates in the normal range, where an increase in either rate raises net revenue.

From the relationship postulated in this tax ellipse, we see that in any region other than $P S$ a lowering of at least one tax rate can be accompanied by a lowering of the other tax rate without reducing total revenue or spending. Only in the $P S$ region does a lowering of one tax rate necessitate a raising of the other rate in order to maintain the same total revenue.

A higher level of tax revenue can be represented by a new tax ellipse inside the one just described; the larger ellipse, then, represents the lower level of revenue. In all cases, four regions would exist. A maximum point of revenue exists beyond which revenue cannot be increased. Whether tax rates are raised or lowered, less revenue will be forthcoming. In sum then, a whole family of isorevenue lines or ellipses exists, one for each level of revenue or spending. The existence of these ellipses allows for a separation of the effects of tax rates per se and total tax revenue or spending.

Combining both the families of iso-revenue and iso-output lines (see figure 3), a number of general propositions and derivations emerge. It is apparent that, for each level of revenue (spending), there exists only one pairing of tax rates that maximizes output. It is determined by the tangency point between the iso-revenue and isooutput lines, i.e., the intersection point closest to the origin, and is designated $O^{*}$. A pairing of tax rates either at point $A$ or point $B$ would yield an iso-output line further from the origin (iso-output line 2). In this case, more revenue could be raised without a loss in output by adjusting tax rates so that the paired tax rates are tangent to iso-output line 2 at point $C$. Such a pairing, of course, would yield a smaller tax ellipse inside the one diagrammed. The smaller ellipse implies more revenue (spending) while output is held constant (isooutput line 2).

Alternatively, output could be expanded, while revenue is held 


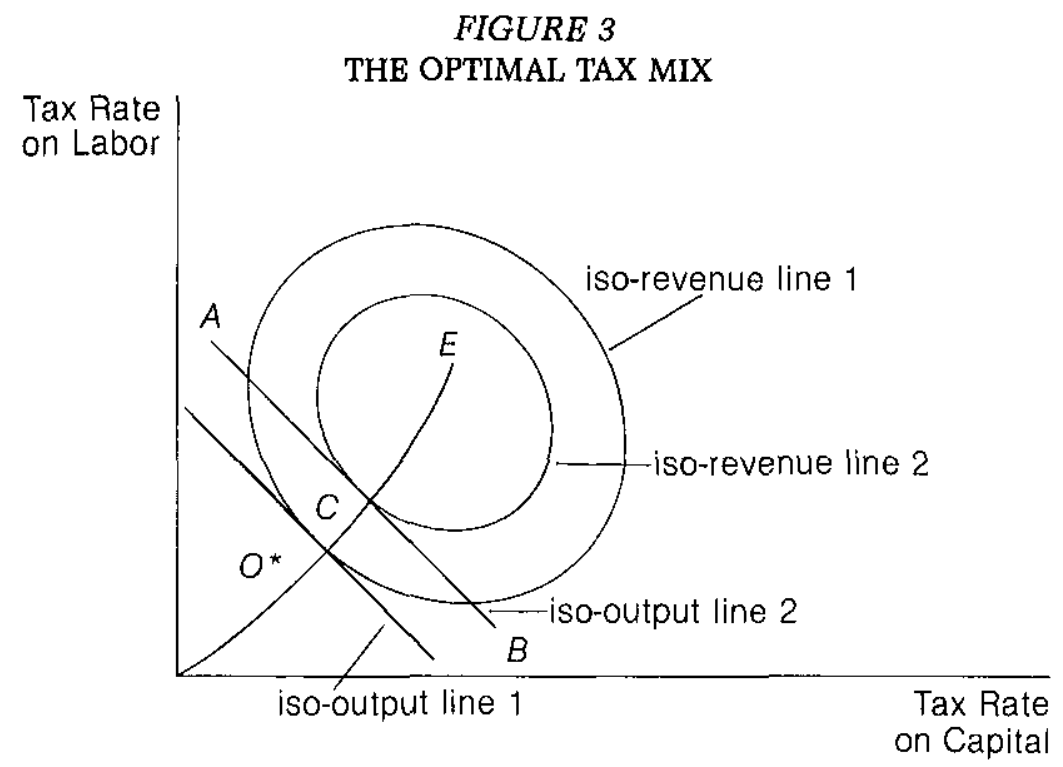

constant, by a shift in the paired tax rates to point $O^{*}$ on the higher (in output) iso-output line 1 . Taking the tax rate pairings that maximized output for a given level of revenue yields the output efficiency line of $E L$. This output efficiency line designates that precise pairing of tax rates for any level of government spending whereby output is least diminished. This output efficiency line traverses points $O^{*}$ and $C$, ending where tax rates equal zero, $L$, and also where tax rates yield the maximum possible amount of revenue, $E .^{3}$

The tax ellipse also may be used to explore the conceptually uitimate effects of different tax pairings on the net wages received and net yields received for each factor of production. Again, the use of the iso-revenue curve allows revenue, and therefore government spending, to be held constant. The tax rate on each factor of production individually is the incidence of the tax. It is depicted explicitly on the tax pairings. The burden of the tax, though, is the actual change in the net wages received and net yields received caused by the tax change.

The incidence of the tax structure is very different from the burden of the tax structure. The person on whom a tax is levied may well experience no loss in net income if he passes the tax forward on to consumers or backward on to suppliers. Likewise, a person

${ }^{3}$ Again, it is important to remember that in the framework used up to this point, all spending is in the form of lump-sum transfers that do not, in and of themselves, enhance output. 


\section{Cato journal}

upon whom no tax has been levied may well suffer large netincome losses (the burden) as a consequence of taxes levied on others.

Within the PS region, an increase in the tax on capital must be accompanied by a reduction in the tax on labor; this is the condition that holds revenue constant. The increase in the tax on capital will reduce the amount of capital employed. This reduction in demand for capital also shifts back the demand for labor. Labor pays less tax, but the reduction in demand for labor services reduces the wages paid. The overall effect of a lower pretax wage and lower taxes on net wages received is ambiguous. In more intuitive terms, as often as not, taxing capital to upgrade labor will damage labor. Similarly, taxing the rich is sometimes a good way to further impoverish the poor.

To summarize: We have five basic points:

1. Changes in tax rates affect output in a direct fashion. Lower tax rates correspond to higher output.

2. Changes in tax rates directly affect the employment of both factors of production. Lower tax rates on either factor increase employment for both factors.

3 . With government spending held constant, the constellation of tax rates affects output. How taxes are collected is important, as is the total amount of taxation and spending.

4. Lowered tax rates on any factor may or may not lower total revenue.

5 . With revenue held constant, changes in the pairing of tax rates may shape the distribution of after-tax spending power, but only indirectly. As often as not, when one factor's tax rate is raised and the other's is lowered, the second factor will end up in worse economic shape.

The theoretical model developed in this section suggests that if the tax rate and the factor supply and demand elasticities could be measured, the determination of whether a tax rate is in the normal or prohibitive range would be straightforward. For the United States economy, such an analysis would employ estimates of the tax rate and of the factor demand and supply elasticities from existing studies to determine the value of the output elasticity with respect to tax rates. One careful study conducted along these general lines is reported in a paper by Don Fullerton of Princeton University. Fullerton's basic conclusion is that while "the U.S. economy could conceivably be operating in the 'prohibitive range' for a na- 
tional tax on labor income, reasonable estimates of an aggregate, economy-wide labor supply elasticity and labor income tax rate are low enough to suggest that a broad-based cut in labor income tax rates would probably lead to lower revenues." ${ }^{\prime 4}$

There are several difficulties with this general approach, however. The first is that labor is not homogeneous, though we assumed it is in our simple model. In reality, both the labor supply elasticity and the marginal income tax rate vary across workers. As Fullerton recognizes, it might be possible that certain groups have such high labor supply elasticities or marginal tax rates that they are currently being taxed at prohibitive levels, even though this would not necessarily show up in a highly aggregated analysis. For example, while most studies show that married males typically have low labor supply elasticities, recent work seems to indicate that females may have quite high supply elasticities. Thus the "'marriage penalty' which places a secondary worker in the higher marginal tax bracket of his or her spouse may represent a high rate of tax on an elastically supplied factor" and may well indicate that married women are being taxed at prohibitive rates. ${ }^{5}$ Also, recent evidence indicates that proprietors of small businesses, who have more control over hours worked than do most employees, may have a considerably higher supply elasticity than do males in general. ${ }^{6}$ Finally, marginal tax rates can be quite high for those in upper income brackets and can be even higher for the poorest workers and those receiving social security, who stand to lose benefit payments as their earnings increase. ${ }^{7}$

Finally, it is not true, as we've assumed up to now, that the tax base is equal to market-sector output. Taxes can be avoided by acquiring tax shelters. This generally involves some cost in inconvenience, lawyers' and accountants' fees, and lower before-tax income. But the higher tax rates are, the more affordable these costs become, and the more tax avoidance and outright evasion people will engage in. It is thus possible that an increase in tax rates may lower revenue even if the elasticity of output with respect to the tax rate is less than unity. For all of these reasons, the approach of examin-

\footnotetext{
${ }^{4}$ Donald Fullerton, "On the Possibility of an Inverse Relationship between Tax Rates and Government Revenues," Working Paper No. 467, National Bureau of Economic Research [New York\}, April 1980.

5 Ibid., p. 20.

6'Terrance Wales, "Estimation of a Labor Supply Curve for Self-Employed Business Proprietors," International Economic Review 14 (February 1973): 69-80.

7 See Arthur B. Laffer, Prohibitive Tax Rates and the Inner-City: A Rational Explanation of the Poverty Trap (Boston: H. C. Wainwright \& Co. Economics, June 27, 1978).
} 


\section{Cato JOURNAL}

ing estimated labor supply elasticities can shed important but only limited light on the issue of whether the United States is currently operating at a prohibitive level of taxation. ${ }^{8}$

\section{Some Historical Antecedents}

Although the empirical relationship among tax rates, economic activity, and tax revenues is presently a matter of some controversy, the idea that excessive tax rates may be counterproductive in raising revenues was explicitly recognized in the early economic literature. The potential for an inverse relationship between tax rates and total revenue was perceived at least as early as the fourteenth century. The Moslem philosopher Ibn Khaldun observed that

at the beginning of the dynasty, taxation yields a large revenue from small assessments. At the end of the dynasty, taxation yields a small revenue from large assessments. ...9

The early economists were also aware that high tax rates may lead to an erosion of the tax base as economic agents switch from the market sector to the underground or subterranean (untaxed) economy. According to Adam Smith,

High taxes, sometimes by diminishing the consumption of taxed commodities, and sometimes by encouraging smuggling, frequently afford a smaller revenue than what may be drawn from more moderate taxes. ${ }^{10}$

Similarly, J. B. Say stated that

taxation, pushed to the extreme, has the lamentable effect of impoverishing the individual, without enriching the state... [T] hus, the taxpayer is abridged of his employment, the producer his profits, and the public exchequer of his receipts. ${ }^{11}$

\footnotetext{
8Since labor mobility means that the elasticity of factor supply to a locality is likely to be much higher than to a country as a whole, it is possible that some localities might be operating in the prohibitive range. For evidence that this is the case, see Ronald E. Grieson, William Hamovitch, Albert M. Levenson, and R. Dale Morgenstern, "The Effect of Business Taxation on the Location of Industry," Journal of Urban Economics 4 (April 1977); and Ronald E. Grieson, "Theoretical Analysis and Empirical Measurements of the Effects of the Philadelphia Income Tax." Journal of Urban Economics, in press. For evidence that tax rates in Sweden exceed those that would maximize revenue, see Charles Stuart, "Swedish Tax Rates in Revenues," mimeographed (University of Lund, Sweden, 1979).

9 Ibn Khaldun, The Muqaddimah; quoted in "Taxation and the Reason for High and Low Tax Revenues," Wall Street Journal, September 30, 1978,"

10Adam Smith, An Inquiry into the Nature and Causes of the Wealth of Nations, ed. $\mathrm{E}$. Canaan (Chicago: University of Chicago Press, 1976).

11 J. B. Say, A Treatise on Political Economy, trans. C. R. Prinsep (New York: Kelley, 1971), p. 449
} 
Smith and Say were thus aware of the substitution effect through which increases in the tax rate reduce the tax base. Furthermore, Say explicitly recognized that the elasticity of revenue with respect to tax rates, even when positive, is less than unity. The resultant decrease in economic activity, he wrote, "is the reason why a tax is not productive to the public exchequer in proportion to its rates, and why it has become a sort of apophthegm, that two and two do not make four in the arithmetic of finance. Excessive taxation ... extinguishes both production and consumption, and the taxpayer into the bargain. ${ }^{12}$ It was apparent to Say that the full effect of taxation goes beyond the mere transfer of resources from the private sector to the public sector: "A tax that robs the individual, without benefit to the exchequer, substitutes no public consumption whatever, in the place of the private consumption it extinguishes. ${ }^{13}$

Later economists also recognized the importance of the particular constellation of tax rates, and of the indirect effects of taxation on the tax revenues collected by other taxes. The nineteenth-century American economist Henry George, in Progress and Poverty, wrote that

the mode of taxation is, in fact, quite as important as the amount. As a small burden badly placed may distress a horse that could carry with ease a much larger one properly adjusted, so a people may be impoverished and their power of producing wealth destroyed by taxation, which if levied another way, could be borne with ease.... ${ }^{14}$

Finally, regarding the indirect feedback effect of a tax, twentiethcentury economist Martin Bronfenbrenner states:

A direct form limits attention to the specific levy under consideration. As applied in direct form, the argument applied to the tax on beer states simply that an increased rate would increase reventues from the tax on beer, and vice versa, An indirect form applies to the general ... tax system. As applied to the beer tax, it states that even though an increased rate may increase receipts from beer, it will decrease receipts from other taxes by more than enough to offset the gross increases.... ${ }^{15}$

This brief survey of economic doctrine has shown that earlier economists, too, recognized the salient features of the model discussed in the first section of this paper.

12 Ibid., p. 450.

13 Ibid.

14 Henry George, Progress and Poverty (New York: Robert Schalkenbach Foundation, 1979], p. 409.

15 Martin Bronfenbrenner, "Diminishing Returns in Federal Taxation?" Joumal of Political Economy 52 (October 1942): 699-717. 


\section{The Example of the "Kennedy" Tax Cuts}

Although the theoretical proposition that increases in tax rates above a certain level may actually reduce revenue is by now widely accepted, ${ }^{16}$ there is considerable disagreement over whether any real-world governments have been observed to operate in the prohibitive range of the "Laffer curve." The remarks cited above indicate that at least some writers regarded prohibitive tax rates not merely as a theoretical possibility, but as an empirical reality. This might not be too surprising when one considers that government in the eighteenth century relied much more heavily on import duties as a source of revenue than do governments today, and that the prohibitive tariff has long been regarded as something more than a theoretical curiosity. Modern governments rely for revenue primarily on broad-based taxes on economic activity, however, and the notion that such governments may be operating in the prohibitive range of the "Laffer curve" meets with considerable resistance. ${ }^{17}$ The issue is essentially an empirical one, and the comments of the eighteenth- and nineteenth-century economists can provide scant evidence on this point.

One approach is to examine past instances of substantial tax rate changes to determine their effects on revenue, although it leaves the final conclusion of whether or not the current tax system is in the prohibitive range a matter of inference and judgment. Controlled experiments are not possible, but the more closely a past ex-

16 Seymour Zucker, alternating quotes from a series of economists, reflects the mainstream of current thought: "To Harvard's Martin Feldstein, the theoretical principle that at some point reducing rate actually increases tax revenues is something we teach in the first week of the course in Public Finance" "Commentaryl Economics," Business Week, August 7, 1978, pp. 62-64).

17 The following quotation clearly illustrates the sentiments of many economists on a broad-based tax rate cut. Herbert Stein, in "The Real Reasons for a Tax Cut" (Wall Street Journal, July 18, 1978), stated that "economists cannot say that they know with certainty that the Kemp-Roth tax cut would not raise the revenue. They can, or should, only say that the available evidence makes that outcome extremely improbable. It may turn out that such a tax cut would raise the revence, just as it may turn out that there is human life on Mars. But I would not invest much in a McDonald's franchise on that planet, and I wouldn't bet the nation's economic policy on the assumption that the tax cut will increase the revenue."

Similarly, in a letter to then House Ways and Means Committee chairman Al Ullman (D-Utah), John Kenneth Galbraith referred with his customary moderation to the Kemp-Roth bill and its revenue-raising potential in these terms: "The notion that the revenue can be recouped from the added output is, of course, egregious and irresponsible nonsense" (Tax Reduction, Economists Comment on H.R. 8333 and $S$. 1860 [Washington, D.C.: U.S. Congress, House Ways and Means Committee, 1978], p. 42). 
perience with tax reduction resembles the current situation, the clearer the implication for current policy.

One such experience was the "Kennedy" tax cuts of 1962 and 1964. There are some obvious differences between the economic environment of the mid-1960s and that of the early 1980s. Inflation and the budget deficit today are at least ten times higher. Unemployment is significantly greater. In addition, the makeup of government spending has shifted away from expenditures related to national defense and the purchase of goods and services to the maintenance of an extensive welfare system. Defense spending in 1979 was 21.3 percent of total federal government expenditures, compared to 46.2 percent in 1962 , while transfer payments have risen to 41.2 percent of federal government expenditures, from 25.1 percent in 1962 .

These differences, however, detract very little from the appropriateness of the comparison between the two periods. The size of the budget deficit is an important consideration when deciding whether or not to reduce tax rates, if revenue is expected to decline. But the size of the deficit has little to do with the issue of whether or not a certain tax is in the prohibitive range. And today's higher rate of inflation will cause any reduction in tax rates to be partially offset as individuals move into higher tax brackets through "bracket creep," reducing the absolute magnitude of any positive or negative change in revenue.

Moreover, there are important similarities between the two time periods. The fundamental institutional framework underlying the economy remains intact: The U.S. economy today has more in common with itself fifteen years ago than it does with, say, Japan or Brazil today. The economy before 1963 , as now, was characterized by lackluster performance. Capacity utilization as measured by the Federal Reserve Board then was 83.3 percent; in the first quarter of 1980 , it was 83.7 percent. Unemployment in 1962 was 6.7 percent.

In addition, there is good evidence that effective tax rates today are higher than they were before the Kennedy tax cuts, thereby increasing the chance that tax rates today are in the prohibitive range. The higher the tax rate, the greater the likelihood that rate cuts will increase revenue. Joines estimates that by the early 1970s the weighted average tax rate on income from capital had risen to roughly the same level as before the Kennedy tax cuts, where it has more or less remained into the present period. ${ }^{16}$ By the mid-1970s,

18Douglas H. Joines, "Estimates of Effective Marginal Tax Rates on Factor Incomes," Joumal of Business, in press. 
FIGURE 4

MARGINAL TAX RATES ON CAPITAL AND LABOR INCOME

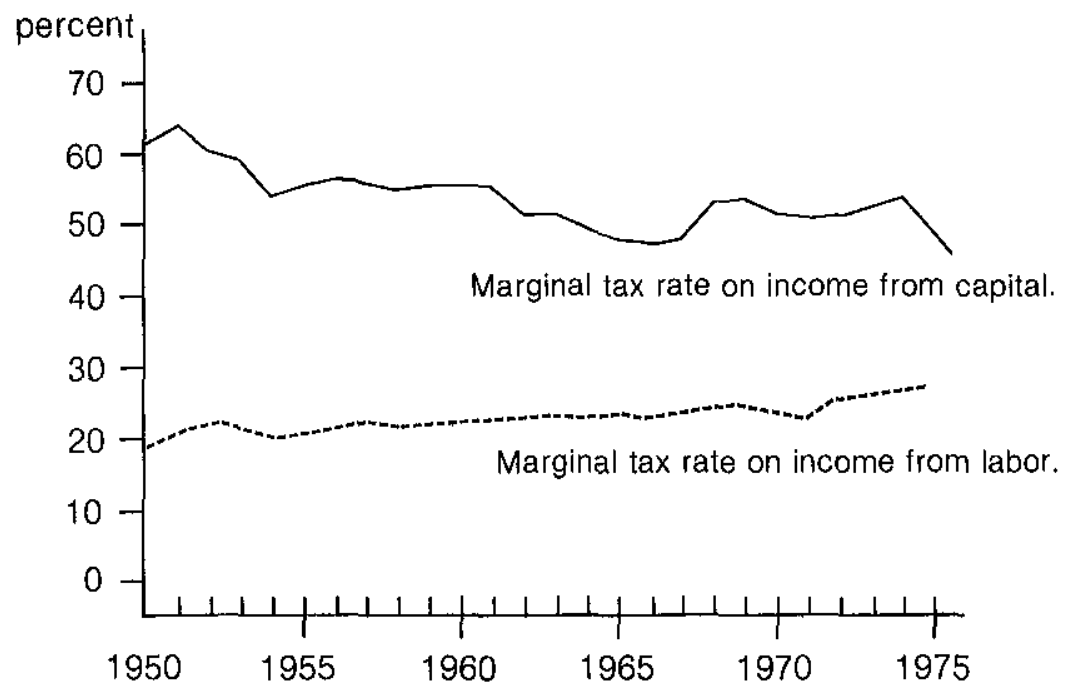

Source: Douglas H. Joines, "Estimates of Effective Marginal Tax Rates on Factor Incomes," The Journal of Business, in press.

the weighted average tax rate on labor income was substantially higher than in 1963 (see figure 4). Three principal factors are behind these increases:

1. Inflation-induced increases in real personal income tax rates, referred to as "bracket creep";

2. The inflation-induced understatement of true economic depreciation and overstatement of real capital gains; ${ }^{19}$

3. Increases in the social security tax rate and wage base.

All of these factors continued after the mid-1970s, until, by 1979 , federal, state, and local personal income tax receipts took 15.6 percent of private personal income (i.e., personal income exclusive of transfer payments to persons| as compared with 11.4 percent in 1963. In 1979 total government receipts constituted 36 percent of GNP, compared with 28.3 percent in 1963 .

These percentages are projected to rise even further in fiscal year 1981 because of continued inflation, further increases in social security taxes, and the enactment of the "windfall profits" tax on

${ }^{19}$ See Arthur B. Laffer and R. David Ranson, Inflation, Taxes and Equity Values (Boston; H. C. Wainwright \& Co. Economics, September 20, 1979). 
domestic oil production. Thus an analysis of the economic and revenue effects of the Kennedy tax cuts would be useful in anticipating the effects of an across-the-board tax cut today. ${ }^{20}$

\section{The Tax Cuts}

The first reduction in effective tax rates during the Kennedy/ Johnson administration was in 1962, when Congress passed an investment tax credit and existing depreciation schedules were liberalized. The tax credit was equal to 7 percent of a firm's investment in producers' durable equipment with a useful life of eight years, and no credit was given for equipment with a useful life of less than four years. The tax credit applicable to utilities was 3 percent, rather than 7 percent. No credit was given for structures. In addition, guidelines published by the Internal Revenue Service for depreciation were revised, substituting classes of assets for an item. by-item delineation. The new guidelines reduced depreciable lives approximately 30 to 40 percent.

In 1964 income-tax rate cuts for both corporations and individuals were enacted. The corporate income tax rate was reduced to 48 percent from 52 percent, and personal income tax rates were reduced across the board, declining to 14 percent from 20 percent at the bottom and to 70 percent from 91 percent at the top (see table 1). In addition, a minimum standard deduction of $\$ 200$ plus $\$ 100$ per exemption was introduced. This had the effect of removing from the tax rolls a substantial number of individuals. Thus the effective tax cut was somewhat larger than the reduction in the tax rates alone suggests. The 1964 tax cuts became law in midyear, with about half of the reductions in tax rates retroactive to the beginning of the calendar year. The full reduction in tax rates became effective in calendar year $1965 .^{21}$

\section{The Economic Effect}

There is general agreement that the Kennedy tax cuts did contribute significantly to the economic expansion of the mid-1960s. Unemployment declined to 3.8 percent in 1966 from 5.6 percent in

20If the economy were more nearly "fully employed" than in 1963, tax rates might have a smaller expansionary effect now than then. Although it is not clear that these numbers are reliable indicators of full employment of available resources, it is worth noting that the total unemployment rate was 5.6 percent in $1963,6.2$ percent in January 1980, and 7.7 percent in June 1980. Similarly, the Federal Reserve Board's index of manufacturing capacity utilization was 83.3 percent in $1963,83.8$ percent in January 1980, and 78.4 percent in June 1980.

${ }^{21}$ See Nicholas J. Gonedes, "Evidence on the Tax Effects on Inflation under Historical Cost Accounting Methods" (unpublished paper, University of Pennsylvania, May 1980 . 


\begin{tabular}{|c|c|c|c|}
\hline IN FED & $\begin{array}{r}\text { TA } \\
\text { THE Ig64 } \\
\text { RAL PERSON }\end{array}$ & $\begin{array}{l}\text { LE } 1 \\
\text { LEDUCTIONS } \\
\text { L INCOME T }\end{array}$ & X RATES \\
\hline $\begin{array}{c}\text { Income Level } \\
\text { (dollars) }\end{array}$ & $\begin{array}{c}\text { Calendar } \\
\text { Years } \\
1954-1963\end{array}$ & $\begin{array}{c}\text { Calendar } \\
\text { Years } \\
1965-1967\end{array}$ & $\begin{array}{l}\text { Percent Reduction } \\
\text { in Tax Rate }\end{array}$ \\
\hline$\$ 0-500$ & $20 \%$ & $14 \%$ & $-30.0 \%$ \\
\hline $500-1,000$ & 20 & 15 & -25.0 \\
\hline $1,000-1,500$ & 20 & 16 & -20.0 \\
\hline $1,500-2,000$ & 20 & 17 & -15.0 \\
\hline $2,000-4,000$ & 22 & 19 & -13.6 \\
\hline $4,000-6,000$ & 26 & 22 & -15.4 \\
\hline $6,000-8,000$ & 30 & 25 & -16.7 \\
\hline $8,000-10,000$ & 34 & 28 & -17.6 \\
\hline $10,000-12,000$ & 38 & 32 & -15.8 \\
\hline $12,000-14,000$ & 43 & 36 & -16.3 \\
\hline $14,000-16,000$ & 47 & 39 & -17.0 \\
\hline $16,000-18,000$ & 50 & 42 & -16.0 \\
\hline $18,000-20,000$ & 53 & 45 & -15.1 \\
\hline $20,000-22,000$ & 56 & 48 & -14.3 \\
\hline $22,000-26,000$ & 59 & 50 & -15.3 \\
\hline $26,000-32,000$ & 62 & 53 & -14.5 \\
\hline $32,000-38,000$ & 65 & 55 & -15.4 \\
\hline $38,000-44,000$ & 69 & 58 & -15.9 \\
\hline $44,000-50,000$ & 72 & 60 & -16.7 \\
\hline $50,000-60,000$ & 75 & 62 & -17.3 \\
\hline $60,000-70,000$ & 78 & 64 & -17.9 \\
\hline $70,000-100,000$ & 87 & 69 & -20.7 \\
\hline $100,000-150,000$ & 89 & 70 & -21.3 \\
\hline $150,000-200,000$ & 90 & 70 & -22.2 \\
\hline 200,000 \& over & 91 & 70 & -23.1 \\
\hline
\end{tabular}

Source: Joseph Pechman, "The Individual Income Tax Provisions of the Revenue Act of 1964," Journal of Finance 20 (May 1965): 247-72.

1963; capacity utilization increased more than 8 percentage points to 91.9 percent in 1966, while real GNP between 1963 and 1966 grew at a compound annual rate of 5.7 percent, compared to just 4.1 percent during the previous three years. Between 1963 and 1966, GNP grew slightly faster than government spending, though government spending had expanded 5 percent more than GNP between 1960 and 1963. And between 1962 and 1966 the ratio of government expenditures to GNP actually fell. It thus seems un- 
likely that the increase in economic activity can be attributed entirely to the stimulus of increased government spending.

\section{The Revenue Effect}

Whether the economy was operating in the prohibitive range, that is, whether this expansion in economic activity and the general tax base associated with the tax cuts was sufficiently large to offset the tax rate reduction's negative revenue effects, is subject to considerable debate. There is substantial anecdotal evidence that highincome individuals were in the prohibitive range. Michael $\mathrm{K}$. Evans's examination of revenue data for the first half of the $1960 \mathrm{~s}$ indicates that revenue from individuals with taxable incomes in excess of $\$ 100,000$ increased from $\$ 2.3$ billion in 1962 to $\$ 2.5$ billion in $1963, \$ 3$ billion in 1964 , and $\$ 3.8$ billion in 1965.22

Viewed in isolation, however, the overall personal income tax schedule appears not to have been in the prohibitive range. With the tax cuts, total personal income tax revenue declined between 1963 and 1964. This suggests that the weighted average of the individual personal income tax rates was in the normal range. The loss in tax revenue from individuals at low income levels exceeded the gain in tax revenue from individuals at high income levels. ${ }^{23}$

A set of revenue loss estimates that allow for any actual feedback of tax rates on economic activity would be useful in anticipating the revenue effects of an income tax cut today similar to the cuts enacted in 1962 and 1964. Such estimates would not be based on any prescribed level of economic activity. First, estimates of what revenue would have been in the absence of tax cuts have to be made. These estimates then must be compared with the actual revenue figures: The difference between the two numbers constitutes an estimate of the revenue change resulting from the tax cuts.

One study conducted along these lines was done by Victor A. Canto, Douglas H. Joines, and Robert I. Webb. ${ }^{24}$ Forecasts of various revenue series for the years immediately following the Kennedy tax cuts were obtained using a statistical analysis of the revenues from the personal income and corporate income taxes at

\footnotetext{
${ }^{22}$ Michael K. Evans, "Taxes, Inflation, and the Rich," Wall Street Joumal, August 7, 1978. Reprinted in Arthur B. Laffer and Jan P. Seymour, eds., The Economics of the Tax Revolt (New York: Harcourt Brace Jovanovich, 1979).

${ }^{23}$ Ibid.

24Victor A. Canto, Douglas H. Joines, and Robert I. Webb, "Empirical Evidence on the Effects of Tax Rates on Economic Activity, Proceedings of the Business and Economic Statistics Section: 1979 (Washington, D.C.: American Statistical Association, 1979).
} 


\section{Cato Journal}

the federal level, and income tax receipts at the state and local level, for the period prior to the tax rate reductions. A univariate time-series model, sometimes referred to as a Box-Jenkins or ARIMA model, was used. A study by Charles Nelson shows that such a technique, despite its simplicity, can be used to forecast a time series using only knowledge of its own past history. ${ }^{25}$ Generally, such an approach will yield forecasts as accurate as, and frequently more accurate than, those obtained from large and complicated econometric models.

In the first step, the time-series models were fit to the two federal revenue series-real personal income tax receipts and real corporate income tax receipts. Fortunately for the purposes of this analysis, there were no major changes in federal tax rates between 1950 and the Kennedy cuts. The variations in revenue collections during those years, therefore, can be attributed to the normal workings of the economy, rather than to changes in tax rates. Furthermore, this period contains a sufficient number of quarterly observations to make identification and estimation of univariate time-series models feasible. Consequently, the time-series models can be used to forecast what revenues would have been if the economy had continued to evolve along its normal path and the Kennedy tax cuts had not been enacted.

Next, Canto, Joines, and Webb compared their results with the estimates made by Pechman and the Treasury Department. ${ }^{26}$ The analysis proceeds through fiscal year 1966, after which Vietnam spending increased markedly, adding a significant fiscal policy change that, in a Keynesian model, would have stimulated economic activity and revenue. The same methodology, a univariate time series, was used to estimate what state and local tax revenues would have been without the change in federal tax policies (i.e., the indirect feedback effects).

Canto, Joines, and Webb concluded that the combined revenue effect of the Kennedy tax cuts on Federal personal income, Federal corporate income, and state and local income tax receipts according to the time series analysis is a loss of $\$ 2.5$ billion (constant $1963: 4$ [i.e., the fourth quarter of 1963] dol-

\footnotetext{
25 Charles R. Nelson, Applied Time Series Analysis for Managerial Forecasting (San Francisco: Holden Day, 1973), and "The Predictive Performance of the FRB-MITPENN Model of the U,S. Economy," American Economic Review 62 (October 1972): 902-17.

26 Joseph Pechman, "The Individual Income Tax Provisions of the Revenue Act of 1964," Journal of Finance 20 [May 1965): 247-72. See also, by the same author, Federal Tax Policy, 3rd ed. (Washington, D.C.: Brookings Institution, 1977).
} 
FIGURE 5

THE CUMULATIVE REVENUE EFFECTS

OF THE KENNEDY TAX CUTS

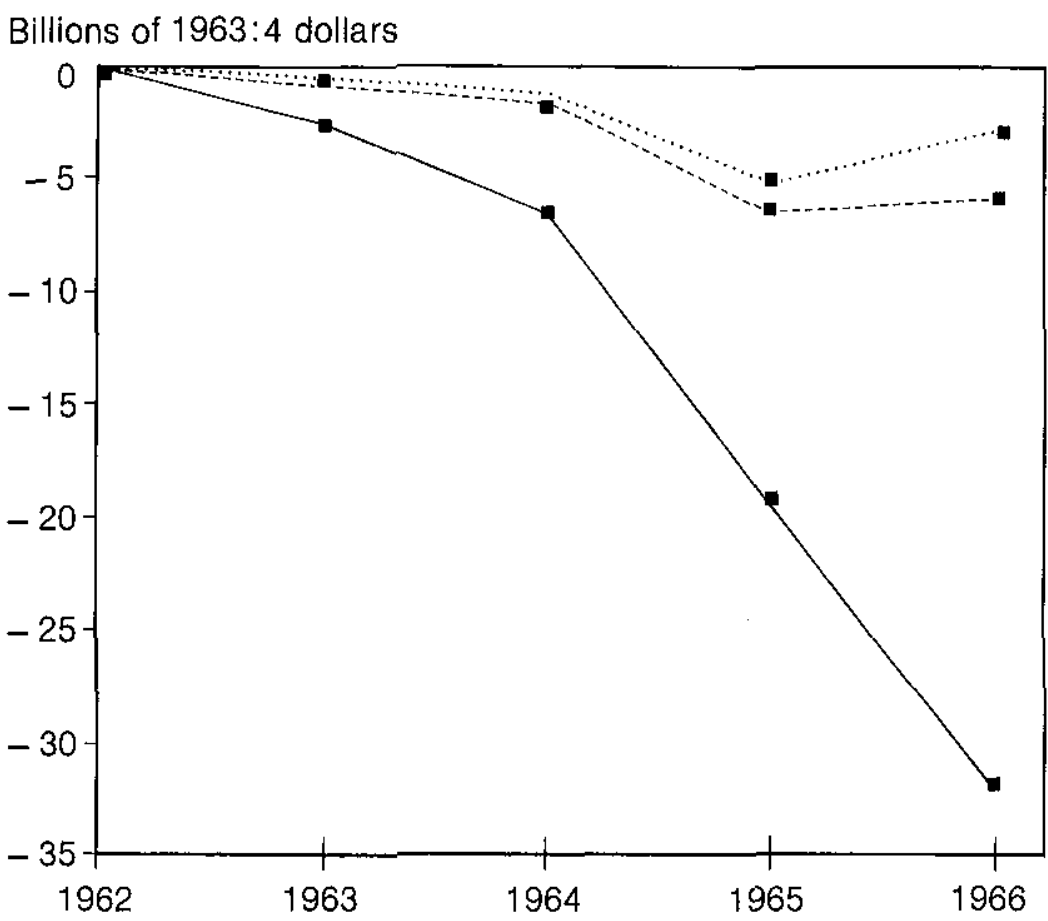

Treasury estimate for cumulative change in federal personat and corporate income tax revenues.

Time series estimate for cumulative change in federal personal and corporate income tax revenues.

Time series estimated for aggregate cumulative change in federal, state, and local personal and corporate income tax revenues.

SourcE: Victor A. Canto, Douglas H. Joines, and Robert I. Webb, "Empirical Evidence on the Effects of Tax Rates on Economic Activity," Proceedings of the Business and Economic Statistics Section: 1979 (Washington, D.C.: American Statistical Association, 1979).

lars) through 1966 [see figure 5]. Given the statistical uncertainty attached to this estimate, it is virtually indistinguishable from zero. Furthermore, it contrasts sharply with the Treasury's estimate of the Federal revenue loss of $\$ 32$ billion (constant $1963: 4$ dollars|; it is quite likely that the static revenue estimates used by 


\section{Cato Journal}

the Treasury back in the mid-1960s, as well as now, greatly overstate the negative revenue effects of Federal tax reductions. These results, on a cumulative basis through 1966, suggest that it is as likely that the Federal tax cuts in 1962 and 1964 increased revenues as that they reduced them. Moreover, the relative gain in Federal personal income tax receipts during the first half of 1966 suggests that in about two years, personal income tax revenues were running ahead of what they would have been without the 1964 tax cut. Furthermore, by 1966, Federal corporate profits tax receipts and state and local income tax receipts appear to have been running ahead of what they otherwise would have been by ever larger amounts. This suggests that if the net effect of the tax cuts could be calculated on a present value basis, with the net changes in the revenue streams extended indefinitely into the future, it would be even more likely to find that the Kennedy tax cuts had been self-financing. ${ }^{27}$

While increased defense spending associated with escalation of the Vietnam War precludes further empirical extrapolation, the trend in revenues is clear: Beginning in fiscal year 1967, the Kennedy tax cuts were paying handsome dividends in the form of higher tax receipts. There is a substantial range of uncertainty in these estimates; nevertheless, the point estimates provided by this study are exceptionally conservative for the overall budgetary effect of the Kennedy tax cuts. Many other tax sources, including state and local property and sales taxes, were not included in the analysis. They, too, would be expected to generate more revenue as the economy expanded. Changes in government spending, if included, also would have led to more sanguine estimates of the net budgetary impact of these tax cuts.

In comparison to the Kennedy tax cuts, the tax rate cut proposed by the Reagan administration (30 percent across-the-board, to be phased in over three years), is modest. Personal income tax rate reductions equivalent (based on GNP) to those passed in 1964 would show a static revenue loss of about $\$ 40$ billion. Equivalent reductions in corporate taxes would show another $\$ 10$ billion reduction in static revenue losses.

By contrast, the first installment of Reagan's personal income tax cut is less than $\$ 20$ billion on a static basis. Moreover, the Kennedy tax cut, which was passed in the spring of 1964, was phased in over two years. The first half was retroactive to the beginning of calendar year 1964, with the full tax cuts being effected on January 1 , 1965. The Reagan tax cut would be phased in over three years. The

${ }^{27}$ Canto, Joines, and Webb, "Empirical Evidence." 
expansion of the economy that would occur in anticipation of the additional reductions in tax rates would reduce further the actual revenue losses relative to those experienced in the mid-1960s. Finally, effective marginal tax rates on both capital and labor are now as high as or higher than they were at the time of the Kennedy cuts. Higher effective tax rates, per se, increase the likelihood that a tax is in the prohibitive range. Thus the revenue feedback effects from across-the-board tax rate reductions are likely be greater than those experienced fifteen years ago.

It is reasonable to conclude that each of the proposed 10 percent reductions in tax rates would, in terms of overall tax revenues, be self-financing in less than two years. Thereafter, each installment would provide a positive contribution to overall tax receipts. By the third year of the tax reduction program, it is likely that the net revenue gains from the plan's first installment would offset completely the revenue reductions attributable to the final 10 percent tax rate cut. It should be noted that a significant portion of these revenues would accrue to state and local governments, relieving much if not all of the fiscal distress evident in these governmental units as well.

As in the 1960s, spending as a percentage of GNP would be expected to decline. The substantially larger portion of the federal budget devoted today to income-maintenance programs makes the expenditure implications of higher-than-expected economic growth an important part of the overall fiscal analysis. Thus the proposed Reagan tax cut has a far better chance of balancing the budget while restoring vitality to the American economy than the programs attempted by the Carter administration. 